\title{
EFFECT OF MILK PROCESSING ON THE DISTRIBUTION OF SOME TRACE ELEMENTS IN ITS PRODUCTS. Mohran, M.A. ${ }^{1}$, Abd El Kher, A.A. ${ }^{2}$, Abd EL Rahim, A.M. ${ }^{1}$ and Ateteallah, H.A. ${ }^{2}$ \\ 1.Dairy Department, Faculty of Agriculture, Assiut University. 2. Dairy Department, Faculty of Agriculture, Sohag University. Corresponding E-mail: mo_ali_3@yahoo.com
}

\begin{abstract}
The effect of some milk processes on the distribution of $\mathrm{Fe}, \mathrm{Zn}, \mathrm{Cd}$ and $\mathrm{Pb}$ elements in the resultant products had been investigated. The levels of these elements in raw milk and the obtained products were estimated in ppm. The distribution in respect of these elements during the separation of buffalo's raw whole milk into cream and skim milk were 9.88 and $90.12 \%$ for $\mathrm{Fe}, 7.37$ and $92.38 \%$ for $\mathrm{Zn}, 5.88$ and $94.10 \%$ for $\mathrm{Cd}$ and 6.99 and $93.01 \%$ for $\mathrm{Pb}$, respectively. The churning process of the above cream into butter and butter milk showed reducing the values of these elements in the resultant butter. It contained 27.10, 16.31, 30.80 and $15.00 \%$ of the cream initial content of $\mathrm{Fe}, \mathrm{Zn}, \mathrm{Cd}$ and $\mathrm{Pb}$, respectively. The major values of the foregoing elements were remainder in butter milk with percentages of $72.89,83.63$, 91.70 and $85.00 \%$ of $\mathrm{Fe}, \mathrm{Zn}, \mathrm{Cd}$ and $\mathrm{Pb}$, respectively. The percentage levels of $\mathrm{Fe}$, $\mathrm{Zn}, \mathrm{Cd}$ and $\mathrm{Pb}$ in the acid curds obtained after direct acidification of the forgoing skim milk as compared with the initial levels were 69.89, 36.11, 60.36 and $78.61 \%$, respectively. The drainage whey contained $63.89,30.20,64.94$ and $58.75 \%$ of these elements in the same respect.
\end{abstract}

Keywords : Trace elements, heavy metals.

\section{INTRODUCTION}

The International Dairy Federation (IDF 1968) issued information about the heavy metals contamination of milk and dairy products followed by further publications. Heavy metals make up on the most important groups in food supply ( Protasowichi, 1992). Heavy metals are considered toxic substances resulting in serious healthy hazards to human and other living organisms through progressive irreversible accumulation in their bodies resulting from repeated consumption of small amounts of such elements Wheaton and Lawson, (1985). Environmental pollution with some heavy metals leads to increase of metal contamination in air, water, milk and various food stuffs had represent an important role in human and animals Crossman, (1981). In recent years, risks of heavy metals that may pollute different foods have been receiving increased attention. Heavy metals contamination of milk is now considered to be a greater problem than that of pesticides (IDF, 1992 and FAO/WHO, 1997). Anetta, et al.; (2012) showed that the toxic metal content of milk and dairy products is due to several factors: environmental conditions, the manufacturing process and the possible contamination during several steps of the manufacturing processes. El-Awamry (1994) studied the fate of some heavy metals during the manufacture of milk. The separation of buffalo's and cow's milk into cream and skim milk however separation processes was more effective in reducing 
the heavy metals potential in the resultant cow's than buffalo's cream. The churning of buffalo's cream into butter reduced the heavy metals potential in obtained butter. Also the manufacture of Kareish cheese from skim milk shows that the heavy metals content was reduced The concentration and retention of some heavy metals in milk and milk products are closely dependent upon manufacturing process, ripening and storage. Further concentration of milk fat to butter and ghee decrease the retention \% levels of all heavy metals than the retention\% in cream out of starting amount in milk Elham, et al.; (2011). Roh, et al.; (1976) studied the distribution of added Cd in milk systems and the feasibility of removing $\mathrm{Cd}$, and concluded that $\mathrm{Cd}$ was not bound strongly to any protein fraction. Kolodkin, et al. (1979) studied the distribution of $\mathrm{Pb}$ in milk fraction and they found that cream $35 \%$ fat contained $15 \% \mathrm{~Pb}$ as initial milk. Rennet casein had less $\mathrm{Pb}$, but had more of the other trace elements than acid casein. They also reported that trace elements were more easily washed out from the milk and its fractions than native elements, the leaching was easier with cream than casein. Mohran, et al $(2011$ a) studied the distribution of $\mathrm{Zn}, \mathrm{Fe}, \mathrm{Cd}$ and $\mathrm{Pb}$ during the separation of raw milk into cream and skim milk. The churning process of cream into butter and butter milk reduced the values of elements in resultant butter.

The aim of present work to follow the concentrations of some trace elements in milk products manufacture from buffalo's milk after the application of some manufacturing process by using inductively coupled plasma atomic emission spectrometry (ICP-OES) in ppm.

\section{MATERIALS AND METHODS}

All chemicals and reagents used in this study were of analytical grade supplied by BDH and Sigma chemical companies. Distilled water was used for the preparation of all solutions. Pyrex glassware was used throughout.

\section{1- Detection of some trace elements}

The occurrence of some elements $\mathrm{Fe}, \mathrm{Zn}, \mathrm{Pb}$ and $\mathrm{Cd}$ in milk, and some dairy products had been estimated in ppm according to the method by James (1995) in Analytical Chemistry of Foods. The obtained ash was dissolved in $5 \mathrm{ml} \mathrm{HCL} \mathrm{(36.6 \% )} \mathrm{and} \mathrm{the} \mathrm{volume} \mathrm{was} \mathrm{completed} \mathrm{to} 50.0 \mathrm{ml}$ by distilled water. The dilutions were applied to the ICAP6200 (ICP - OES) to estimate the levels of $\mathrm{Fe}, \mathrm{Zn}, \mathrm{Cd}$ and $\mathrm{Pb}$ (ppm) of the Central laboratory for Chemical Analysis, Faculty of Agriculture , Assiut University.

2- Determination the distribution of $\mathrm{Fe}, \mathrm{Zn}, \mathrm{Cd}$ and $\mathrm{Pb}$ in some milk products as affected with their manufacturing process.

Fresh buffalo's milk was obtained from the herd of Assiut Governorate and added with $\mathrm{Cd}$ and $\mathrm{Pb}(5 \mathrm{ppm})$ of each and with $\mathrm{Fe}$ and $\mathrm{Zn}$ (10 ppm) of each. About of $2 \mathrm{~kg}$ of raw fresh buffalo's milk was applied to centrifugation at $3000 \mathrm{rpm}$ to separate cream from defatted milk. The quantities of both cream and defatted milk were determined. The levels of the four above elements were detected and their quantities were calculated. A quantity of obtained cream was churned to butter and butter milk. The concentrations of tested elements in both of butter and butter milk were 
estimated and quantity calculated. The defatted milk was transferred to acidified soft cheese by direct acidification using glacial acetic acid. The levels of investigated elements in both of cheese and its whey were detected and quantity calculated. The percentage values of the foregoing elements in the previous products were calculated as compared with their initial quantities.

\section{RESULTS AND DISCUSSIONS}

Impact of milk processing on some trace element distributions:

Distributions of some trace elements include $\mathrm{Fe}, \mathrm{Zn}, \mathrm{Cd}$ and $\mathrm{Pb}$ during the production of some dairy products was shown in diagrams 1,2 and 3 .

1. Separation of Cream:

Distribution of some elements during the centrifugation of raw milk into cream and skim milk was shown in diagram (1).

Diagram (1) : Distribution of elements in skim milk (SM) $(1.5 \mathrm{~kg})$ and cream (C) $(0.25 \mathrm{~kg})$ obtained from Raw milk $(1.750 \mathrm{~kg})$

Total content (mg) 
It was found that $9.88,7.36,5.88$ and $6.99 \%$ of $\mathrm{Fe}, \mathrm{Zn}, \mathrm{Cd}$ and $\mathrm{Pb}$ elements as related to the initial quantities in raw milk are separated with cream. On the other hand, skim milk contained 90.12, 92.38, 94.13 and 93.01 $\%$ of these metals respectively. The results revealed that most investigated trace elements were separated with skim milk and ranged from 90.12 to $94.13 \%$. This result may be due either to the binding of these elements with casein or to solubility in milk serum. This finding was in agreement with the data obtained by Roh, (1975); Mathur, and Roy, (1978) and Mohamed, (2008). Also El-Awamry, (1994) referred that separation processes reduce the heavy metals potential in the resultant cream.

2.Churning of Cream into Butter and Butter milk (Laban Khad):

Diagram (2) showed that the distribution of some elements during churning cream into butter and Laban khad manufacturing throughout.

Diagram (2): Distribution of elements in Laban Khad $(0.15 \mathrm{~kg})$ and Butter $(0.1 \mathrm{~kg})$ obtained from Cream $(0.250 \mathrm{~kg})$

Total content $(\mathrm{mg})$ 
It was observed that the Churning processes reduced the trace elements pollution in the resultant butter, which contained 27.10, 16.31, 8.3 and $15.00 \%$ as percentage of the initial of $\mathrm{Fe}, \mathrm{Zn}, \mathrm{Cd}$ and $\mathrm{Pb}$ in cream in the same respect. On the other side the removal metals in Laban Khad (Butter milk) were $72.89,83.63,91.70$ and $85.00 \%$ for $\mathrm{Fe}, \mathrm{Zn}, \mathrm{Cd}$ and $\mathrm{Pb}$, respectively. This may be attributed to their solubility in milk serum. The obtained results were in agreement with that obtained by Abou Arab, (1991); El-Awamry, (1994) and Mohamed, (2008)

3. Manufacture of Acidic curd

Diagram (3) represents the distribution of $\mathrm{Fe}, \mathrm{Zn}, \mathrm{Cd}$ and $\mathrm{Pb}$ of skim milk that coagulated by direct acidification between resultant curd and its Whey.

Diagram (3): Distribution of elements in Acidic curd $(0.4 \mathrm{~kg})$ and its Whey $(1.1 \mathrm{~kg})$ obtained from Skim milk $(1.50 \mathrm{~kg})$

\section{Total content (mg)}


$\mathrm{t}$ was found that curd kept $69.98,36.11,35.06$ and $40.78 \%$ of $\mathrm{Fe}, \mathrm{Zn}$, $\mathrm{Cd}$ and $\mathrm{Pb}$ as percentage of initial skim milk content of these elements in the same respect, while the residuals of investigated elements were removed in whey with 30.2, 63.89, 64.94 and $58.75 \%$, respectively. The elements concentrations in the acidic curd were higher than those recorded by Mohamed, (2008). The higher contents of investigated elements in the acidic curd than the fatty dairy products may be attributed to that these elements bound strongly with casein component or casein micelles.

\section{REFERENCES}

Anetta, L.; Peter, M.; Agnieszka. G. and Josef, G. (2012). concentration of selected elements in raw and ultra heat treated cow milk. Journal of Microbiology, Biotechnology and Food Sciences, (2) : 795-802.

Crossman, G. (1981). Further ungsweise Arch Lebensmittel. Hyg, 32: 87-89.

El-Awamry, Z. K. (1994). Reduction of the adverse effects of some chemical pollutant of milk in Egypt. Ph.D. Institute of environmental and Research. Ain Shams Univ., Cairo, Egypt.

Elham, M. E.; Sanaa, M. B.; Amr, A. M. and Ahmed, M. H. (2011). Evaluation of the factors influencing the content and retention of selected heavy metals in milk and some dairy products. International Journal of Dairy Science, 6: 305-313

FAO/WHO (1997). General requirements (Food Hygiene). Codex Alimentarius, Vol. 1B (suppl). Food and Agriculture Organization, Rome.

I.D.F (1992). International Dairy Federation, Trace elements in milk and milk products. Bulletin of the International Dairy Federation. No.278,88pp.

James, C. S. (1995). Analytical Chemistry of Foods. Blackie Academic and Professional, London. England.

Kolodkin, A. M.; Ogneva, E. Y. A.; Elizareva and Ognev, V. R. (1979). Distribution of trace elements in milk and it constituents. Pishchevaya Teknol. 1:16.

Mathur, O. N. and Roh, J. K. (1978). Studies on trace minerals in buffaloes milk. II. Iron, Zinc, Sulphur and Boron. International Dairy Congress Vol. E.: 50-51.

Mohamed, T. H. (2008). Fate of certain trace elements in milk during the manufacturing of some dairy products. Ph. D. Thesis, Fac. Agriculture. Assiut Univ. Egypt

Mohran, M. A., El-Gendy, Sh. M., Said, A. I. and Mohamed, T. H. (2011a). The occurrence of certain elements in milk and some dairy products. 2Effect of milk processing on the distribution of $\mathrm{Zn}, \mathrm{Fe}, \mathrm{Cd}$ and $\mathrm{Pb}$ in the resultant products. Egypt.J. Agric. Res., 89 (2): 651-663.

Protasowicki, M. (1992). Heavy metals content in the selected Food. $3^{\text {rd }}$ world congress, food born infection and intoxication 16-19, Jun, Berlin.

Roh, J. K.; Bradly, R. L.; Richardson, T. and Weckel, K. G. (1976). Distribution and removal of cadmium from milk. J. Dairy Sci., 59: 376381 
Wheaton, F.W. and Lawson, T.B. (1985). Processing of aquatic food products. Aweily Inter Science Publication P. 231-232. John Weily and Sons, New York. Toronto.

تاثير العمليات التصنيعية للبن علي توزيع بعض العناصر النادرة في منتجاتة

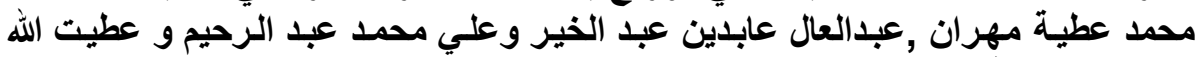

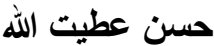
قسم الالبان- كلية الزراعة. جامعة اله اسيوط قسم الالبان- كلية الزراعة- جامعة سوهاج الزية

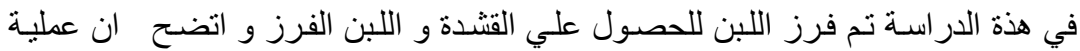

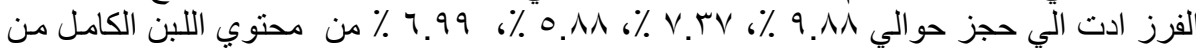

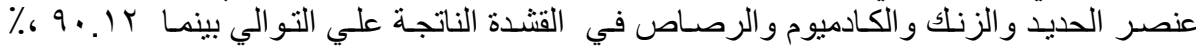

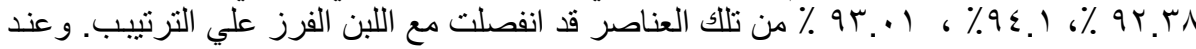

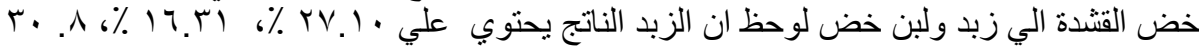

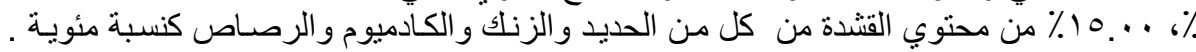

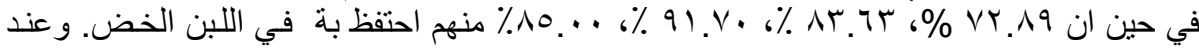

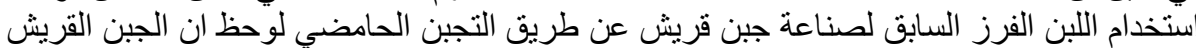

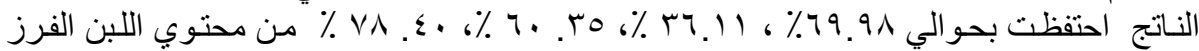

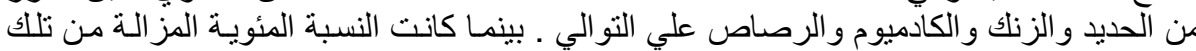

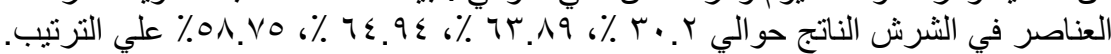

